\title{
HEALTH BENEFITS, EXTRACTION AND UTILIZATION OF DIETARY FIBERS: A REVIEW
}

\author{
Magida M. El-Habashy \\ Food Science and Technology Dept. Fac. of Agric., Menoufia University, Egypt.
}

Received: Mar. 14, 2017

Accepted: Mar. 21, 2017

\begin{abstract}
Dietary fiber (DF) is that part of plant material in the diet which is resistant to enzymatic digestion and includes cellulose, polysaccharides such as hemicellulose, pectin substances, gums, mucilage and a non-carbohydrate component lignin. DF is often divided into two parts when it is dispersed in water: a soluble and an insoluble fraction, each fraction has different physiological effects. High-fiber diets are associated with the prevention and treatment of some diseases such as constipation, diverticular disease, colonic cancer, coronary heart disease and diabetes. Daily intake for total fiber for adults has been set at $38 \mathrm{~g}$ for men and 25 $g$ for women. DF is obtained by different methods and from different sources. The amount and composition of fiber differ from one food to another. DF from cereal bran is a typical ingredient in high DF food products, but the presence of soluble DF in cereals is quite low, this is not the case with fruits where the ratio between soluble and insoluble DF fractions is more balanced. Influence of different processing treatments (like extrusion-cooking, canning, grinding, boiling, frying) alters the physico-chemical properties of dietary fiber and improves their functionality. Dietary fiber can provide a multitude of functional properties when they are incorporated in food systems. Thus, fiber addition contributes to the modification and improvement of texture, sensory characteristics and shelf-life of foods due to their water binding capacity, gel-forming ability, fat mimetic, antisticking, anticlumping, texture rising and thickening effects. Dietary fiber can be used in various functional foods like bakeries, drinks, beverages and meat products. Dietary fiber can be determined by different methods, mainly by enzymatic gravimetric and enzymatic chemical methods.
\end{abstract}

Key words: Dietary fiber, sources, classification, preparation, application, health benefits.

\section{INTRODUCTION}

Dietary fiber (DF) was originally defined in 1972 by Trowell as "that portion of food which is derived from cellular walls of plants which are very poorly digested by human beings". American Association of Cereal Chemists (AACC 2000) defined DF as the edible parts of plant or analogous carbohydrates that are resistant to digestion and absorption in the human small intestine with complete or partial fermentation in the large intestine. The 2009 Codex definition of dietary fiber is "carbohydrate polymers with 10 or more monomeric units, which are not hydrolysed by the endogenous enzymes in the small intestine of humans and belonging to the following categories: 1. Edible carbohydrate polymers naturally occurring in the food as consumed. 2. Carbohydrate polymers, obtained from food raw material by physical, enzymatic or chemical means, 3. Synthetic carbohydrate polymers. (Jones 2014). Worldwide there is a 'fiber gap' because intake is far below the recommendations. Indigestible dietary fiber is metabolized by gut bacteria, including Faecalibacterium prausnitzii, which has a critical role in colonic homeostasis owing to a variety of functions. Dietary fiber intake has been significantly inversely associated with the risk of chronic diseases (Mitsuro et al., 2015). Dietary fiber is often classified as soluble dietary fiber (SDF) and insoluble dietary fiber (IDF), refering to fiber dispersability in water (Gorinstein, et al., 2001).

Dietary fiber is naturally present in cereals, vegetables, fruits and nuts. The 
amount and composition of fibers differ from food to food (Desmedt and Jacobs 2001). DF from cereals are more frequently used than those from fruits, however, fruit fiber have better quality due to higher total and soluble fiber content, water and oil holding capacity and colonic fermentability as well as lower phytic acid content and caloric value (Larrauri, et al.,1997). It is generally accepted that those fiber sources suitable for use as food ingredient should have a SDF/IDF ratio close to 1:2 (Jaime, et al., 2002). Over the past two hundred years diet has become increasingly processed, leading to greatly reduced fiber content (Burkitt and Trowell, 1975 \& Kendall et al., 2010). The importance of food fibers has led to the development of a large and potential market for fiber-rich products and ingredients. In recent years, there is a trend to find new sources of dietary fiber that can be used in the food industry (Chau and Huang, 2003). Supplementation has been used to enhance fiber content of foods such as snack foods, beverages, spices, imitation cheeses, sauces, frozen foods, canned meats and meat analogues (Hesser, 1994). Supplementation has been focused on cookies, crackers and other cereal-based products. Dietary supplements are typically marketed in the form of capsules, pills, powder or gel and are not presented for use as a conventional food, meal or diet. Dietary supplements contain one or more dietary ingredients (e.g., vitamins, minerals, amino acids, herbs or other botanicals) (U.S. Food and Drug Administration, 1994; van Kreijl et al., 2006; Eussen et al., 2011).

A fiber-rich diet is low in energy density, often has a low fat content, large in volume and is rich in micronutrients (Rolls, et al., 1999). Dietary fiber plays an important role in human health, it acts as a protective agent against cardiovascular diseases, diverticulosis, constipation, irritable colon, obesity, colon cancer and diabetes (Gorinstein, et al., 2001, \& Rodriguez, et al., 2006). The physiological effects are related to the physico-chemical and functional properties of dietary fiber. It is widely known that dietary fibers obtained by different methods and from different sources, behave differently during their transit through the gastrointestinal tract, depending on their chemical composition and physico-chemical characteristics and on the processing that foods undergo (Chau and Huang, 2003; Herbafood et al., 2002 \& Jimenez, et al., 2000).

During processing, the foods undergo various physical, chemical, enzymatic and thermal treatments, which directly or indirectly affect the composition of total fiber. Incorporation of fiber can change the consistency, texture, rheological behavior and sensory attributes of the end products (Guillon and Champ 2000).

According to Larrauri (1999), the "ideal dietary fiber" should meet the following requirements: have no nutritionally objectionable components; be as concentrated as possible; be bland in taste, color and odor; have a balanced composition and adequate amount of associated bioactive compounds; have a good shelf life; be compatible with food processing; have the expected physiological effects. Therefore, this contribution provides an overview of key research, describing the dietary fibers profile associated with health promoting activities, including the impact of dietary fiber sources and processing.

\section{Classification of Dietary Fiber}

Historically dietary fiber was classified as soluble and insoluble based on whether they form a solution when mixed with water (soluble), or not (insoluble) (Periago, et al., 2013). Soluble Dietary Fiber (SDF) sometimes called "prebiotic" or "viscous", absorbs water to form a viscous "gel" and is fermented by bacteria in the digestive tract resulting in production of gases, hence possible sensation of "bloating" (Gibson and Roberfroid, 1995 \& Fuller and Gibson, 1997). SDF include pectin, oligosaccharides, guar, and gums, most of which are dietary 


\section{Health benefits, extraction and utilization of dietary fibers: A review}

and healthy additives. IDF mainly consist of hemicellulose, cellulose, and lignin and cannot be degraded by enzymes in the human body (Dhingra et al., 2012). Insoluble dietary fiber (IDF) does not ferment but absorbs water while passing through the digestive system, resulting in bulky yet soft faeces, easing defecation. Soluble fiber can help lower blood cholesterol and glucose levels, which is found in oats, peas, beans, apples, citrus fruits, carrots and barley. Insoluble fiber can be of benefit to those who struggle with constipation or irregular stools. Whole-wheat flour, wheat bran, nuts, beans and vegetables, such as cauliflower, green beans and potatoes, are good sources of insoluble fiber. Classification of dietary fiber components based on water solubility/fermentability is presented in table (1).

Table 1: Classification of dietary fiber components based on water solubility/fermentability.

\begin{tabular}{|c|c|c|c|}
\hline Characteristic & $\begin{array}{c}\text { Fiber } \\
\text { component }\end{array}$ & Description & Main food sources \\
\hline Water & Cellulose & $\begin{array}{l}\text { Main structural component of } \\
\text { plant cell wall. Insoluble in } \\
\text { concentrated alkali, soluble in } \\
\text { concentrated acid. }\end{array}$ & $\begin{array}{l}\text { Plants (vegetables, sugar } \\
\text { beet, various brands) }\end{array}$ \\
\hline $\begin{array}{l}\text { insoluble/ } \\
\text { less } \\
\text { fermented }\end{array}$ & Hemicellulose & $\begin{array}{l}\text { Cell wall polysaccharides, } \\
\text { which contain backbone of } \beta- \\
1, \quad 4 \text { glucoside Linkages. } \\
\text { Soluble in dilute alkali. }\end{array}$ & Cereal grains \\
\hline \multirow{4}{*}{$\begin{array}{l}\text { Water } \\
\text { soluble/ } \\
\text { Well } \\
\text { fermented }\end{array}$} & Lignin & $\begin{array}{l}\text { Non-carbohydrate cell wall } \\
\text { component. Complex Cross- } \\
\text { linked phenyl propane } \\
\text { polymer. Resists bacterial - } \\
\text { degradation. }\end{array}$ & Woody plants \\
\hline & Pectin & $\begin{array}{l}\text { Components of primary cell } \\
\text { wall with D-galacturonic acid } \\
\text { as principal } \\
\text { component. } \\
\text { Generally water soluble and } \\
\text { gel forming. }\end{array}$ & $\begin{array}{l}\text { Fruits, vegetables, } \\
\text { legumes, sugar beet, } \\
\text { potato }\end{array}$ \\
\hline & Gums & $\begin{array}{l}\text { Secreted at site of plant injury } \\
\text { by specialized secretary cells. } \\
\text { Food and pharmaceutical use. }\end{array}$ & $\begin{array}{l}\text { Leguminous seed plants } \\
\text { (guar, locust bean), } \\
\text { seaweed extracts } \\
\text { (carrageenan, alginates), } \\
\text { microbial gums (xanthan, } \\
\text { gellan). }\end{array}$ \\
\hline & Mucilages & $\begin{array}{l}\text { Synthesized by plant, prevent } \\
\text { desiccation of seed } \\
\text { endosperm. } \\
\text { Food industry use, hydrophilic, } \\
\text { stabilizer. }\end{array}$ & $\begin{array}{l}\text { Plant extracts (gum } \\
\text { acacia, gum karaya, gum } \\
\text { tragacanth) }\end{array}$ \\
\hline
\end{tabular}




\section{The health benefits of dietary fiber}

Much of the recent literature has revolved around the ability of certain dietary fiber types to affect different physiological systems to understand how dietary fiber influences the characteristics and fermentation patterns of the intestinal microbiome in humans. It is now possible to understand the prebiotic function of fibers using new DNA sequencing procedures that permit complete characterization of the bacterial populations (microbiome) (Wilson, et al., 2010).

Over the years, dietary fiber has received much positive attention with regard to its potential as a pharmafood, due to its ability to reduce cholesterol (Andreasen, et al., 2001; Anderson et al., 2009; Cui, et al., 2011 \& Ajila and Prasada Rao, 2013), diabetes and coronary heart disease, prevention and treatment of obesity (Davidson and McDdonald, 1998; Bingham et al., 2003; Mann and Cummings, 2009 \& Elleuch et al., 2011) and ease constipation (Telrandhe et al., 2012; Rodriguez et al., 2006 \& Hauner et al., 2012). Nowadays, research show that the ingestion of suitable quantities of food fiber produces many beneficial effects on the digestive tract, such as the regulation of the intestinal function, improvement of the tolerance to glucose in diabetics (Pins et al., 2002 \& Ajila and Prasada, 2013) or prevention of chronic diseases as colon cancer (Mongeau, 2003) and anti-carcinogenic effects (Scharlau et al., 2009 \& Ajila and Prasada, 2013). Also, several fibers have demonstrated, in vitro, and in vivo, their capacity for adsorbing carcinogenic agents, (Steinmetz and Potter, 1991; Slavin, 2001 \& Rodríguez et al., 2006).

In a Harvard study of over 40,000 male health professionals, researchers found that a high total dietary fiber intake was linked to a 40 percent lower risk of coronary heart disease and lower risk of metabolic syndrome, such as high blood pressure, high insulin levels, excess weight (especially around the abdomen), high levels of triglycerides, and low levels of HDL (good) cholesterol (Pereira et al., 2004). Several studies suggest that higher intake of fiber may offer protective benefits from this syndrome (McKeown et al., 2002, 2004). Eating dietary fiber, particularly insoluble fiber, was associated with about a 40 percent lower risk of diverticular disease (Aldoori et al., 1998). One of Harvard studies found that dietary fiber was not strongly associated with a reduced risk for either colon cancer or polyps (a precursor to colon cancer) (Fuchs et al., 1999). A large-scale 2016 study led by researchers at Harvard T.H. Chan School of Public Health showed that higher fiber intake reduces breast cancer risk. (Farvid et al., 2016).

The diets with a high content of fiber, such as those rich in cereals, fruits and vegetables have a positive effect on health since their consumption has been related to a decreased incidence of several types of diseases as due to its beneficial effects like increasing the volume of fecal bulk, decreasing the time of intestinal transit, cholesterol and glycemic levels, trapping substances that can be dangerous for the human organism (mutagenic and carcinogenic agents), stimulating the proliferation of the intestinal flora... etc. (Heredia et al., 2002 \& Beecher 1999). Summary of functions and health benefits of DF presented in table (2) .

Guar gum is readily fermented by the human fecal microbiota (Salyers et al., 1977), improves bowel functioning and relieves constipation in patients (Takahashi et al. 1994). Gear et al., (1979), It has been postulated that the fiber may act as a protective factor in cancer of the large bowel by shortening transit time, thus reducing the time for formation and action of carcinogens. In addition, through its stool-bulking effect, fiber may lower the concentration of fecal carcinogens thereby reducing the amount of carcinogen that comes in contact with the gut wall. The large amount of fiber from fruits, vegetables and legumes is partly responsible for the low levels of plasma 


\section{Health benefits, extraction and utilization of dietary fibers: A review}

cholesterol (Anderson et al., 1973). Pectin (Kay and Truswell 1977), guar gum and gum arabic also show a hypolipidemic effect in humans, lowering both serum cholesterol and triglycerides (Takahashi et al., 1993). Dietary fiber can prevent the absorption of harmful substances but will also prevent the absorption of proteins, inorganic salt and some minerals in food, a problem for people who need more of these nutrients, such as actively growing teenagers (Yue-yue et al., 2017).

\section{How much fiber do you need?}

Recommended adult intakes for total fiber range from 21 to $40 \mathrm{~g} /$ day in countries which have developed guidelines. These guidelines came from the recommendation of consuming $14 \mathrm{~g} / 1000 \mathrm{kcal}$, and then converting the value to $\mathrm{g}$ of fiber/d based on energy intake. This means that the higher the recommended energy intake level, the higher the fiber recommendation. The World Health Organization has recommended that total fiber intake be $25 \mathrm{~g} /$ day (WHO/FAO, 2003 \& Food and Nutrition Board, Institute of Medicine, 2001). Numerous health organizations suggest increasing the consumption of DF, to $30-45 \mathrm{~g}$ per day (Bonfeld, 1985; Eastwood, 1987; GrigelmoMiguel et al., 1999a). This current DRI value is an adequate intake level and is based on the decreased risk of coronary heart disease with dietary fiber consumption (Alinorm, 2010). Daily intake for total fiber for adults has been set at $38 \mathrm{~g}$ for men and $25 \mathrm{~g}$ for women (Trumbo, et al., 2002; Soukoulis et al., 2009 \& Ramirez-Santiago et al., 2010). Recommendations for both genders at all age groups (Table 3). Thus, girls and women in each age group have a lower recommended value than do boys or men.

Table 2: Functions and benefits of dietary fiber on human health.

\begin{tabular}{|c|c|}
\hline Functions & Benefits \\
\hline Adds bulk to the diet, making feel full faster & May reduce appetite \\
\hline $\begin{array}{l}\text { Attracts water and turns to gel during digestion, trapping } \\
\text { carbohydrates and slowing absorption of glucose }\end{array}$ & Lowers variance in blood sugar levels \\
\hline Lowers total and LDL cholesterol & Reduces risk of heart disease \\
\hline Regulates blood pressure & $\begin{array}{l}\text { May reduce onset risk or symptoms of } \\
\text { metabolic syndrome and diabetes }\end{array}$ \\
\hline Speeds the passage of foods through the digestive system & Facilitates regularity \\
\hline Adds bulk to stool & Alleviates constipation \\
\hline $\begin{array}{l}\text { Balances intestinal } \mathrm{pH} \text { and stimulates intestinal } \\
\text { fermentation }\end{array}$ & May reduce risk of colorectal cancers \\
\hline
\end{tabular}

Source: (Devinder et al., 2012).

Table 3: Recommended adequate intake levels for fiber gram/day.

\begin{tabular}{|c|c|c|}
\hline Age, year & Male & Female \\
\hline & $g / d$ & \\
\hline $1-3$ & 19 & 19 \\
\hline $4-8$ & 25 & 25 \\
\hline $9-13$ & 31 & 26 \\
\hline $14-18$ & 38 & 26 \\
\hline $19-50$ & 38 & 25 \\
\hline 51 & 30 & 21 \\
\hline
\end{tabular}

Adapted from (Institute of Medicine, National Academy of Sciences 2005).

Adequate Intakes for females are increased to $28 \mathrm{~g} / \mathrm{d}$ during pregnancy and to $29 \mathrm{~g} / \mathrm{d}$ for lactation. 
Using of too much fiber can prevent the absorption of minerals by the body as iron, zinc, calcium and magnesium. Using of high fiber in a short time may cause gas, bloating, and abdominal cramps. Therefore, gradually increasing fiber in nutrition will protect from these side effects. (Erişim tarihi., 2013).

Fiber supplements are also available to increase the intake of dietary fiber; however, most experts recommend that fiber should be obtained through the consumption of foods, because this form allows consumption of many micronutrients and bioactive compounds contained in high-fiber foods, which provide their own nutritional benefits.

\section{Some tips for increasing fiber intake}

Eating whole fruits instead of drinking fruit juices, 2. Replace white rice, bread, and pasta with brown rice and whole grain products, 3. For breakfast, choose cereals that have a whole grain as their first ingredient, 4. Snack on raw vegetables instead of chips, crackers, or chocolate bars, 5. Substitute beans or legumes for meat two to three times per a week, also, 6.Drink plenty of water. Fiber works best when it absorbs water, making stool soft and bulky. Getting enough fiber is important for overall health and disease prevention.

\section{Sources of the Dietary Fiber.}

Dietary fiber is naturally present in cereals, vegetables, fruits and nuts. The amount and composition of fibers differ from food to food (Desmedt and Jacobs 2001). Several non-starch food provide up to 20-35 $\mathrm{g}$ of fiber/100 $\mathrm{g}$ dry weight and those containing starch provide about $10 \mathrm{~g} / 100 \mathrm{~g}$ of dry weight and the content of fiber of fruits and vegetables is $1.5-2.5 \mathrm{~g} / 100 \mathrm{~g}$ of dry weight (Selvendran and Robertson 1994). Lambo et al., (2005) reported, cereals to be one of the main sources of dietary fiber, contributing to about $50 \%$ of the fiber intake in western countries, $30-40 \%$ dietary fiber may come from vegetables, about $16 \%$ from fruits and the remaining $3 \%$ from other minor sources. Dietary fiber content of various foods is presented in table (4). Fiber can even be produced from sources that might otherwise be considered waste products. For example, wheat straw, soy hulls, oat hulls, peanut and almond skins, corn stalks and cobs, spent brewers grain and waste portions of fruits and vegetables processed.

\section{Obtaining and Analysis of Dietary Fiber:}

Recent development in dietary fiber methodology has adopted two general approaches (Asp, 2001): enzymegravimetric and enzyme- chemical methods. Enzyme-gravimetric methods, it involves enzyme treatments for starch and protein removal, precipitation of soluble fiber components by aqueous ethanol, isolation and weighing of the dietary fiber residue and correction for protein and ash in the residue (Asp and Johansson 1981; Asp, et al. 1992).

According to Hong, et al., (2012) generally, there are three methods to gain dietary fiber: Chemical method, physical method and microbial fermentation. Removal of starch and protein can be more complete using chemical method, but the poor selectivity, side-effects and difficultly controlled extraction conditions greatly limit its use (Wang, et al., 2004 \& Du, et al., 2005). What are worse, hemicellulose and soluble dietary fiber which play an important role in physiological function are soluble in alkaline solution. Thus, this method can cause the undesired decrease of overall physiological activity (Zhang, et al., 2011). Physical method, such as extrusion cooking, does not cause degradation of the polymer structure or some other deep damage. Therefore, the side chain group can be preserved almost intact, which enables the cation exchange capacity not to be impacted (Ma, et al., 2005; Liu, et al., 2005 \& Jacobs and Delcour, 1998). Recently, microbial fermentation of dietary fiber has been widely 
recognized and accepted due to the high selectivity, mild and easily controlled reaction conditions (Liu, 2008). It has also the advantage of not destroying the structure of natural fiber and no loss of important physiologically functional SDF and hemicellulose. However, the microbial fermentation itself is still in its infancy stage and microbial fermentation of DF may produce toxic substances, thus affecting its safety (Li., 2003). The method was based on the enzymatic removal of protein from the material and the separation into soluble and insoluble fractions by centrifugation, Figure (1), (Mańas, 1992 \& Grigelmo, et al., 1999). The experimental procedure followed by Manaas, (1992) was a modification of the AOAC method (Prosky, et al., 1984).

Table 4: Dietary fiber content of various food sources ( $\mathrm{g} / 100 \mathrm{~g}$ edible portion).

\begin{tabular}{|c|c|c|c|c|c|c|c|}
\hline Dietary fiber & Total & Insoluble & Soluble & Dietary fiber & Total & Insoluble & Soluble \\
\hline Grains & & & & Cucumbers, peeled & 0.6 & 0.5 & 0.1 \\
\hline Barley & 17.3 & - & - & Cauliflower, raw & 1.8 & 1.1 & 0.7 \\
\hline Corn & 13.4 & - & - & Celery, raw & 1.5 & 1 & 0.5 \\
\hline Oats & 10.3 & 6.5 & 3.8 & Carrot, raw & 2.5 & 2.3 & 0.2 \\
\hline Rice (dry) & 1.3 & 1 & 0.3 & Broccoli, raw & 3.29 & 3 & 0.29 \\
\hline Rice(cooked) & 0.7 & 0.7 & 0 & Fruits & & & \\
\hline Wheat(whole grain) & 12.6 & 10.2 & 2.3 & Apple, unpeeled & 2 & 1.8 & 0.2 \\
\hline Wheat germ & 14 & 12.9 & 1.1 & Kiwi & 3.39 & 2.61 & 0.8 \\
\hline Legumes \& pulses & & & & Mango & 1.8 & 1.06 & 0.74 \\
\hline Green beans & 1.9 & 1.4 & 0.5 & Pineapple & 1.2 & 1.1 & 0.1 \\
\hline Soy & 15 & - & - & Pomegranate & 0.6 & 0.49 & 0.11 \\
\hline Peas, green frozen & 3.5 & 3.2 & 0.3 & Watermelon & 0.5 & 0.3 & 0.2 \\
\hline Kidney beans, canned & 6.3 & 4.7 & 1.6 & Grapes & 1.2 & 0.7 & 0.5 \\
\hline Lentils, raw & 11.4 & 10.3 & 1.1 & Oranges & 1.8 & 0.7 & 1.1 \\
\hline Lima beans, canned & 4.2 & 3.8 & 0.4 & Plums & 1.6 & 0.7 & 0.9 \\
\hline White beans, raw & 17.7 & 13.4 & 4.3 & Strawberry & 2.2 & 1.3 & 0.9 \\
\hline Vegetables & & & & Bananas & 1.7 & 1.2 & 0.5 \\
\hline Potato, no skin & 1.3 & 1 & 0.3 & Peach & 1.9 & 1 & 0.9 \\
\hline Bitter gourd & 16.6 & 13.5 & 3.1 & Pear & 3 & 2 & 1 \\
\hline Beet root & 7.8 & 5.4 & 2.4 & Nuts and seeds & & & \\
\hline Fenugreek leaves & 4.9 & 4.2 & 0.7 & Almonds & 11.2 & 10.1 & 1.1 \\
\hline Ladies finger & & 3 & 1.3 & Coconut, raw & 9 & 8.5 & 0.5 \\
\hline Spinach, raw & & 2.1 & 0.5 & Peanut, dry roasted & 8 & 7.5 & 0.5 \\
\hline Turnips & & 1.5 & 0.5 & Cashew, oil roasted & 6 & - & - \\
\hline Tomato, raw & & 0.8 & 0.4 & Sesame seed & 7.79 & 5.89 & 1.9 \\
\hline $\begin{array}{ll}\text { Green } & \text { onions, } \\
\text { raw } & \\
\end{array}$ & & 2.2 & 0 & Flaxseed & 22.33 & 10.15 & 12.18 \\
\hline Eggplant & & 5.3 & 1.3 & & & & \\
\hline
\end{tabular}




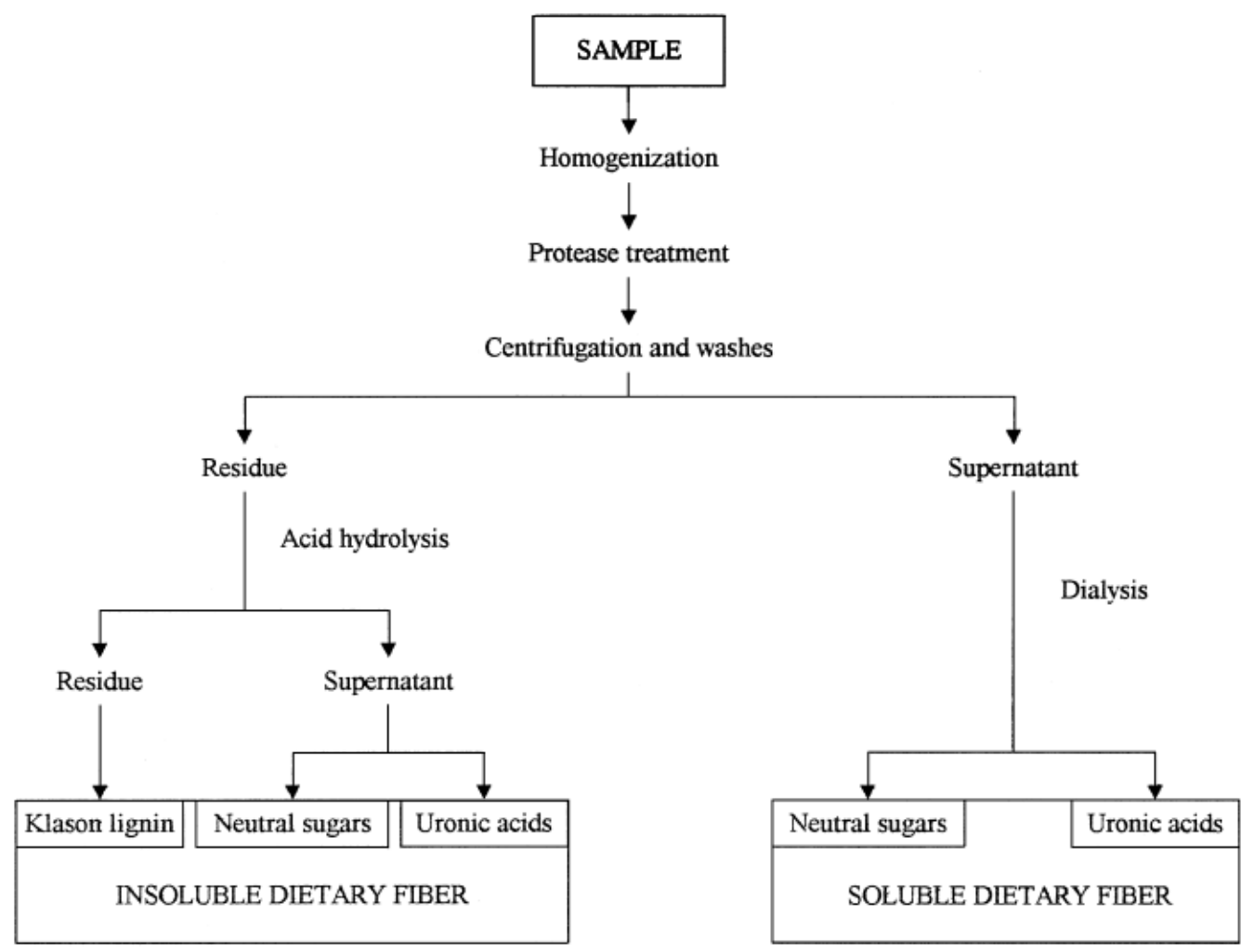

Figure (1): Flow diagram for dietary fiber analysis procedure (Filiz Yangilar et al., 2013).

Enzyme-chemical methods, these methods involve enzyme removal of starch, precipitation with $80 \% \quad(\mathrm{v} / \mathrm{v})$ ethanol to separate the soluble dietary fiber polysaccharides from low molecular weight sugars and starch hydrolysis products. Enzyme-gravimetric methods involves enzyme treatments for starch and protein removal, precipitation of soluble fiber components by aqueous ethanol, isolation and weighing of the dietary fiber residue and correction for protein and ash in the residue (Asp and Johansson 1981 \& Asp, et al., 1992). Chemical analysis is generally used to determine the components of dietary fiber, and is often combined with enzymatic methods by using enzymatic treatment to remove the starch and using anhydrous ethanol for precipitation to obtain total dietary fiber. HPLC can be used to determine the composition of dietary fiber by chemical analysis. HPLC is a relatively mature method and shows good repeatability and high precision (Redondo 1994). FT-IR spectroscopy can also be used to determine fruit dietary fiber composition (Chylinska 2016).

Mongeau and Brooks (2016), presented a brief overview and comparison of common methods for quantifying DF in food. Schweizer and Wursch (1979) employed GLC method for the characterization of gravimetrically determined soluble dietary fiber residues. Graham et al., (1988) examined the influence of extraction conditions on the solubility of dietary fiber in four cereals (wheat, rye, barley and oats) and four vegetables (potato, carrot, lettuce and peas). It was observed that the extraction at high temperature gave the highest values for soluble fiber, whereas the extraction in the acidic buffer gave the lowest value. Larrauri, (1999), described the procedure to obtain DF powders from fruit by-products. $\mathrm{Ng}$, et al., (2010), extracted and 
characterized of DF from coconut residue. Vajiheh and Mania (2012), extracted DF from rice husk by the chemical and enzymatic methods. Dietary fibers were prepared as alkali- and acid-insoluble fractions with chemical phosphorylation from various foods. The dietary fiber fractions treated with alkaline solution and followed by phosphorylation with sodium metaphosphate had the lower protein content, higher total dietary fiber content and water holding capacity than those of the preparations without phosphorylation treatment.

The optimum extraction of banana peel cellulose (BPC) and bleaching conditions included using $90 \%$ ethanol for $16 \mathrm{~h}$ for fat removal, followed by sodium hydroxide $\mathrm{pH}$ 11.6 for $24 \mathrm{~h}$ for elimination of protein, and soaking in $15 \%$ hydrogen peroxide for $3 \mathrm{~h}$ for bleaching. The obtained BPC was washed and dried at $60 \mathrm{C}$ for $10 \mathrm{~h}$. (Singanusong, et al., 2013). Qi et al., (2011), studied the effect of cellulase on extraction rate of SDF and IDF, and optimize the effects of the cellulase that included four factors: the time, temperature, $\mathrm{pH}$ of cellulase action, and the rate of cellulase.

\section{Effect of Food Processing on Dietary Fibers}

Modification methods are used to transform IDF into SDF for better physicochemical and physiological properties (Feng et al., 2017). Modification methods include mechanical degradation "extrusion cooking, high pressure, heating, or novel technology to mechanically disrupt the fiber", chemical treatment use chemical reagents such as acid and alkali to break down dietary fiber, enzymatic, and microbiological fermentation methods. Typically, a combined method may have greater effects than any single approach. For example, chemical-enzymatic, ultrasound-enzymatic, and microwave enzymatic.

Extrusion cooking had a positive effect on total and soluble dietary fiber. The insoluble dietary fiber decreased appreciably with the varying processing parameters, probably due to disruption of covalent and non covalent bonds in the carbohydrate and protein moieties leading to smaller and more soluble molecular fragments. Additionally, the water solubility index was greatly enhanced by varying extrusion temperature and screw speed (Feng et al., 2017).

Liu et al. studied the use of instantaneous high pressure for soybean dreg dietary fiber and found significantly increased soluble dietary fiber content after treatment. Additionally, the physical characteristics (expansibility, water holding capacity, water- binding ability, and specific surface area) of the modified dietary fiber were deferent from those of the unmodified dietary fiber (Huang and Ma 2016).

Carboxymethylation is also frequently used as a method of chemical modification and effects dietary fiber. A study reported improved SDF for dietary fiber extracted from whole grain barley by carboxymethylation (Park et al., 2013). Enzymatic modification uses enzymes to degrade the dietary fiber, decreasing IDF and improving SDF. Microbial fermentation uses organic acids and enzymes produced naturally by microorganisms to reduce the molecular weight and improve the solubility of dietary fiber (Yang, et al., 2017).

The physico-chemical properties of fiber can be manipulated through treatments such as chemical, enzymatic, mechanical (grinding), thermal or thermo mechanical (extrusion, cooked-extrusion). Grinding may affect the hydration properties, in particular, the kinetics of water uptake as a result of the increase of surface area, the fibers hydrate more rapidly. Heating generally changes the ratio of soluble to insoluble fiber. Simple processes such as soaking and cooking tend to modify the composition and availability of nutrients. Processes, such as grinding, drying, heating or extrusion cooking for example, modifies the physical properties of the fiber matrix and also affect 
the hydration properties (Thibault, et al., 1992).

Honcu, et al., (2016) concluded that extrusion process is able to modify the physico-chemical properties of barley fiber components. $\mathrm{Ng}$, et al., (1999) found that extrusion cooking increased the solubility of pectic polymers and hemicelluloses accompanied by an increase in swelling of the cell-wall material. Larrea, et al., (2005) modified the properties of fiber components in orange pulps using extrusion technology. They reported that extrusion conditions decreased IDF and increased SDF.

In wheat bran, it has been found that thermal treatments (boiling, cooking or roasting) originate an increase of total fiber that is not due to new synthesis, but rather to the formation of fiber-protein complexes that are resistant to heating and are quantified as dietary fiber (Caprez, et al., 1986). During cooking of lentils previously dipped, the quantity of fiber diminishes, fundamentally due to great decrease in hemicelluloses (Vidal-Valverde, et al., 1992).

The effects of thermal treatment (including extrusion cooking, boiling and frying) on the dietary fiber composition of cereals and potato samples were studied by Varo, et al., (1983), heat treated potato samples contained more water insoluble dietary fiber and less starch than raw samples. No changes were observed in the amounts of dietary fibers and starch in the extruded samples. The effects of domestic cooking on dietary fiber and starch composition of processed potato products were evaluated by Thed and Phillips (1995), they reported that microwave heating and deep fat frying significantly increases both the resistant starch (RS) and water-insoluble dietary fiber (IDF). Water-soluble dietary fiber content was not affected by any of the domestic cooking methods.

Chopra, et al., (2009) studied the effect of soaking on insoluble, soluble and total dietary fiber of Bengal gram, cow pea, dry pea, field bean and green gram. Samples were soaked in tap water $(1: 2)$ for $12 \mathrm{~h}$ at room temperature $\left(29-31^{\circ} \mathrm{C}\right)$. Soaking increased total dietary fiber by $8.2 \%$ and a considerable increase in soluble dietary fiber was observed. Raghavendra, et al., (2006) evaluated the grinding characteristics of coconut residue and observed that the reduction in the particle size from 1,127-550 $\mu \mathrm{m}$ resulted in increased hydration properties, Beyond $550 \mu \mathrm{m}$, the hydration properties were found to decrease with decrease in particle size during grinding. The fat absorption capacity was also reported to increase with decrease in particle size.

Camire and Flint, (1991) observed an increase in total non-starch polysaccharides in oat meal and potato peels with extrusion and baking processes, but the ratio of soluble to insoluble non-starch polysaccharides was higher in the extruded samples. The process of extrusion increased the hydration capacity of corn meal and oat meal but the hydration capacity of processed potato peels was observed to be lower than raw peels.

The environmental conditions such as temperature, $\mathrm{pH}$, ionic strength, dielectric constant of the surrounding solution and nature of the ions can also influence the hydration characteristics of fiber containing poly-electrolytes (charged groups such as carboxyl in fibers rich in pectin, carboxyl and sulfate groups in fibers from algae) (Fleury and Lahaye 1991 \& Renard et al., 1994). Supercritical $\mathrm{CO} 2$ affects pear pomace insoluble dietary fiber physicochemical properties, the glucose adsorption capacity and glucose retardation. Index of IDF were significantly higher after supercritical $\mathrm{CO} 2$ treatment. (Chang, et al., 2016).

\section{Application of Dietary Fiber in Food Industry}

Dietary fibers can provide a multitude of functional properties when incorporated in food systems. Thus, addition of fibers 
contributes to the modification and improvement of the texture, sensory characteristics and shelf-life of foods due to their water binding capacity, gel-forming ability, fat mimetic, antisticking, anticlumping, texturising and thickening effects (Dello Staffolo, et al., 2004; Gelroth and Ranhotra, 2001 \& Thebaudin and Lefebvre 1997). Most commonly, dietary fibers are incorporated into bakery products to prolong freshness, thanks to their capacity to retain water, thereby reducing economic losses. Fibers can modify bread loaf volume, its springiness, the softness of the bread crumbs and the firmness of the loaf (Sangnark and Noomhorm, 2004 \& Wang, et al., 2002). Dietary fibers from different sources have been used to replace wheat flour in the preparation of bakery products. Pomeranz, et al., (1977) used cellulose, wheat bran and oat bran in bread making. Potato peel, a by-product from potato industry, rich in dietary fiber, was used as a source of dietary fiber in bread making (Toma, et al., 1979 \& Sudha et al., 2007).

Among foods enriched in fiber, the most known and consumed are breakfast cereal and bakery products such as integral breads and cookies (Cho and Prosky, 1999; Nelson, 2001 \& Rodríguez, et al., 2006), as well as milk and meat derived products. The addition of DF to bakery products also improves their nutritional quality since it makes possible to decrease the fat content, by using DF as substitute of fat without loss of quality (Byrne, 1997; Martin, 1999 \& Rodríguez, et al., 2006). Isolated fiber components such as resistant starch and Bglucans are also used for increasing fiber content in pastries, breakfast cereal,... etc. (Knuckles, et al., 1997 \& Rodríguez, et al., 2006). Comprehensive evaluation of potential applications of dietary fibers in flour products, addressing common problems such as dark color and rough texture and reviewing potential solutions (Wen Han et al., 2017).

Introduce of dietary fiber in meat products has been shown to improve cooking yield, water binding, fat binding, and texture (Cofrades, et al., 2000). Fiber addition in meat products may effectively increase acceptability by giving meat products higher quality, improving the processing characteristics, the yield and lengthening the shelf time of meat products, (Talukder, 2015). Dietary fiber and soy protein preparations due to their functional properties are extensively used in many branches of the food industry, including the meat sector (Bilska, et al., 2002; Hoogenkamp, 2007; Jiménez-Colmenero, et al., 2005; Makała and Olkiewicz, 2004; Pietrasik and Duda, 2000 \& Waszkowiak and Szymandera-Buszka 2008). Dietary fber has been used as a fat substitute and added into sausages (Ham, et al., 2016).

Citrus fiber may be incorporated into a broad range of products. For example meat products (Alesón-Carbonell, et al., 2005 \& Fernández-López et al., 2007), fish (Sanchez-Zapata et al., 2008 \& ViudaMartos et al., 2010). Viuda-Martos, et al., (2010), analyzed the effect of orange dietary fiber (ODF), oregano essential oil (OEO) and the storage conditions (vacuum, air and modified atmosphere) on the shelf-life of bologna sausage. ODF and OEO samples stored in vacuum packaging showed the lowest aerobic and lactic acid bacteria count. The sensory evaluation scores were similar for samples with ODF and OEO, and stored either in air or vacuum packaging. Orange dietary fiber, cellulose, soy, wheat, maize or rice isolates and beet fiber can be used for improving the texture of meat products, such as sausages, salami. At the same time, they are adequate to prepare low-fat products, such as 'Dietetic hamburgers'. Since they have the ability of increasing the water retention capacity, their inclusion in the meat matrix contributes to maintain its juiciness (Chevance, et al., 2000 \& Mansour and Khalil 1999).

Oat bran or oat fiber appears to be suitable fat replacement in ground beef and pork sausage products due to its ability to 
retain water and emulate particle definition in ground meat in terms of both color and texture (Verma and Banerjee, 2010). In an attempt to develop low salt, low fat and high fiber functional chicken nuggets, Verma, et al., (2009) incorporated various fiber sources like, pea hull flour, grain hull flour and apple pulp at $10 \%$ level.

The use of fibers in dairy products is also widespread, e.g., inulin introduces numerous improvements into dairy products. It improves body and mouth feel in cheese analogues or ice-cream, and reduces syneresis in yoghurt and other fermented milk products (Blecker, et al., 2001). Soukoulis, et al., (2009), investigated the effects of four dietary fiber sources (oat, wheat, apple and inulin) on the rheological and thermal properties of model sucrose polysaccharides solutions and ice cream mixes. The content of fiber in insoluble compounds, significantly increased the viscosity and the shear thinning behavior of the model solutions and ice creams, due to the increase of total solids and the formation of networks comprised of hydrated cellulose and hemicellulose. The increase of soluble material did not significantly alter the rheology of the samples but limited the freezing point depression and elevated the glass transition temperatures, indicating a potential cryoprotective action. The use of oat and wheat fiber favored viscosity development due to water-binding. Whereas inulin caused a remarkable increase of glass transition temperature $(\mathrm{Tg})$ in model solutions and ice cream mixes, indicating the reduction of water mobility from the bulk aqueous phase to the ice crystals' surface. Apple fiber addition greatly increased viscosity and elevated the $\mathrm{Tg}$ values, particularly in the presence of proteins. Results suggested that the potential use of dietary fibers as crystallization and recrystallization phenomena controllers in frozen dairy products.

Fagan, et al., (2006), studied the effects of soluble dietary fiber inclusion on milk coagulation kinetics. Addition of $2 \%(\mathrm{w} / \mathrm{w})$ inulin was required to decrease gel time and coagulum firming time and no discernible difference was observed between the inulin enriched and control gels. Pectin $(0.2-0.4 \%$ $(\mathrm{w} / \mathrm{w}))$ significantly reduced gel times. Above $0.2 \%(\mathrm{w} / \mathrm{w})$, added pectin increased coagulum firming times and resulted in a limited casein network developing. Dietary fiber (DF) extracted from date flesh showed a high water-holding capacity $(\sim 15.5 \mathrm{~g}$ water/g sample) and oil-holding capacity ( 9.7 g oil/g sample) and pseudo plasticity behavior of their suspensions. Thus, date DF concentrates may not only be an excellent source of DF but an ingredient for the food industry (Elleuch, et al., (2008).

Garcia-Perez, et al. (2005) reported that yogurt containing $1 \%$ orange fiber had a lighter, more red and yellow color and showed lower syneresis than the control and yogurt containing $0.6 \%$ and $0.8 \%$ orange fiber. Addition of $0.5 \%$ barley $\beta$ - glucan or inulin and guar gum (>2\%) were effective in improving serum retention and viscoelastic properties of low-fat yogurt (Brennan and Tudorica 2008). Incorporation of fiber obtained from asparagus shoots, increased yogurt consistency and imparted a yellowish greenish color to the yogurt (Sanz, et al., 2008). Some types of soluble fibers, such as pectin, inulin, guar gum and carboxymethyl-cellulose, are utilized as functional ingredients in the milk products (Nelson, 2001). Fermented milk enriched with citrus fiber (orange and lemon) had good acceptability (Sendra, et al., 2008). Dello Staffolo, et al., (2004) observed the yogurt fortified with $1.3 \%$ wheat, bamboo, inulin and apple fibers appeared to be promising avenue for increased fiber intake, with higher consumer acceptability. Hashim, et al., (2009) studied the effect of fortification with date fiber, a by-product of date syrup production, on fresh yogurt. Yogurt fortified with $3 \%$ date fiber resulted in similar sourness, sweetness, firmness, smoothness and overall acceptability as the control yogurt. 
Sharif, et al., (2009) concluded that replacement of wheat flour with defatted rice bran could be used without adversely affecting physical and sensory characteristics of cookies. Rice bran supplementation significantly improved the dietary fiber, mineral and protein content of the cookies. Addition of fiber ingredients such as alginates, guar gums and cellulose gels not only replaces fat but also serves to provide viscosity, improve emulsion, foam, freeze/thaw stability, control melting properties, reduce syneresis, promotes formation of smaller ice crystals and facilitate extrusion (Alexander, 1997). Coffee grounds were added to cookies for increased dietary fiber source, resulting in more nutritious and more flavorful cookies with potential value in the prevention of diabetes (Martinez-Saez et al., 2017).

In case of beverages and drinks, the addition of dietary fiber increases their viscosity and stability, soluble fiber being the most used because it is more dispersible in water than insoluble fiber. Oat fiber can be incorporated into milk shakes, instant typebreakfast drinks, fruit and vegetable juices, ice tea, sports drinks, cappuccino and wine. Other beverages that can benefit from the addition of fiber include liquid diet beverages- both those created for people with special dietary needs as well as weight loss or meal replacement beverages (Hegenbart, 1995). Larrauri, et al., (1995) described the manufacture of powdered drink containing dietary fiber from pineapple peel. The product, called FIBRALAX, contained $25 \%$ dietary fiber and $66.2 \%$ digestible carbohydrates, and provided a mild laxative effect.

\section{Conclusions}

Dietary fiber is primarily derived from plant material and is composed of complex, non starch carbohydrates and lignin that are not digestible within the small intestine. Fiber is commonly classified as soluble or insoluble. Each fraction has different physiological effects. Dietary fiber plays an important role in human health; it is showing protective effects toward cardiovascular disease, diverticulosis, constipation, irritable colon, colon cancer, obesity, and diabetes. DF also prevents the absorption of proteins, inorganic salt and some minerals in food, which is a problem for people who need more of these nutrients, such as actively growing teenagers. Dietary fibers from cereals are more frequently used than those from fruits; however, fruit fiber have better quality due to higher total and soluble fiber content, water and oil holding capacity and colonic fermentability, as well as lower phytic acid content and caloric value. It is recommend that fiber be obtained through the consumption of foods, because this form allows consumption of many micronutrients and bioactive compounds. Daily intake of total fiber for adults has been set at $38 \mathrm{~g}$ for men and $25 \mathrm{~g}$ for women. Adding too much fiber can quickly promote intestinal gas, abdominal bloating and cramping. Fiber increase in diet should be gradual over a period of few weeks with drinking plenty of water. This allows the natural bacteria in digestive system to get adjusted to the change. Also, fiber works best when it absorbs water, making stool soft and bulky. To avoid intolerance to grain and legume we should look for other fiber sources such as vegetables, fruits and other seeds/nuts. Fiber supplements don't provide the micronutrients, phytochemicals, and water found in whole plant foods.

Dietary fiber analysis methodology has adopted two general approaches, enzymegravimetric and enzyme-chemical methods. The physico-chemical properties of fiber can be manipulated through treatments such as chemical, enzymatic, mechanical (grinding), thermal or thermo mechanical (extrusion). Dietary fibers can provide a multitude of functional properties when incorporated in food systems, contributing to the improvement of food texture, sensory characteristics and shelf-life of foods, due to their water binding capacity, gel-forming and fat mimetic ability, anti-sticking, and 
thickening effects. Addition of fiber ingredients such as alginates, guar gums and cellulose gels not only replaces fat, but also serves to provide viscosity, improve emulsion, foam, freeze/thaw stability, control melting properties, reduce syneresis, promotes formation of smaller ice crystals and facilitate extrusion.

\section{REFERENCES}

A.A.C.C. (2000). Approved methods of American Association of Cereal Chemists $\left(10^{\text {th }}\right.$ ed.). Published by American Association of Cereal Chemists, Ins. Saint Paul, Minnesota, USA.

A.O.A.C, Association of Official Analytical Chemists (1985). Official Methods of Analysis, 14th ed. Washington, DC.

A.O.A.C. (2000). Official Methods of Analysis $\left(17^{\text {th }}\right.$ ed.). Arlington, VA: Association of Official Analytical Chemists, AOAC International, 2000.

Ajila, C., M. Prasada and U. J. S. Rao (2013). Mango peel dietary fiber composition and associated bound phenolics. Journal of Functional Foods. 5: 444-450.

Aldoori, WH, E.L. Giovannucci, H.R. Rockett, L. Sampson, E.B. Rimm and W.C. Willett (1998). A prospective study of dietary fiber types and symptomatic diverticular disease in men. J. Nutrition, 128:714-9.

Alesón-Carbonell, L., J. Fernandez-Lopez, J. A. Perez-Alvarez and V. Kuri (2005). Functional and sensory effects of fiberrich ingredients on breakfast fresh sausages manufacture. Food Science and Technology International, 11 (2): 8997.

Alexander, R. J. (1997). Moving toward lowcalorie dairy products. Food Prod Des 7(1):74-98.

ALINORM (2010). Report of the 30th session of the CODEX committee on nutrition and foods for special dietary uses, cited from: http://www.codexalimentarius.net/downlo ad/report/710/al32_26e.pdf.
Anderson, J., F. Grande and A. Keys (1973). Cholesterol lowering diets: experimental trials and literature reviews. J Am Diet Assoc. 62:133-142.

Anderson, J. W., P. Baird, R. H. Davis, Jr. S. Ferreri, M. Knudtson, A. Koraym, V. Waters, and C.L. Williams (2009). Health benefits of fiber. Nutrition Reviews, 67: 188-205

Andreasen, M. F., A.K. Landbo, L. P. Christensen, A. Hansen and A. S. Meyer (2001). Antioxidant effects of phenolic rye extracts, monomeric hydroxycinnamates, and ferulic acid dehydrodimers on human low-density lipoproteins. Journal of Agricultural and Food Chemistry, 49: 4090-4096.

Asp NG (2001). Development of dietary fiber methodology. In: McCleary, BV, and L. Prosky (eds.) Advanced dietary fiber technology. Blackwell Science Ltd, Oxford, pp. 77-88.

Asp, N.G. and C.G. Johansson (1981). Techniques for measuring dietary fiber. In: James, W.P.T., and O. Theander (ed.). The analysis of dietary fiber in food. Marcel Dekker, New York, pp. 173-189.

Asp, N.G., T.F. Schweizer, D.A.T. Southgate and O. Theander (1992). Dietary fiber analysis. In: Schweizer, T.F. and C.A. Edwards (eds.) Dietary fiber. A component of food. Nutritional function in health and disease. Springer- Verlag, London, pp. 57-102.

Beecher, G.R. (1999). Phytonutrients role in metabolism: effects on resistance to degenerative processes. Nutr Rev 57:63.

Bilska, A., K. Krysztofiak, P. Sęk, and W. Uchman (2002). Influence of the use of the Vitacel preparation on the quality of "lunch meat" sausages. Acta Scientarum Polonorum -Technologia Alimentaria, 1 (1): 47-53.

Bingham, S. A. (2003). Dietary fiber in food and protection against colorectal cancer in the european prospective investigation into cancer and nutrition (EPIC) an observational study. The Lancet, 361: 1496-1499. 
Bjerrum, K. S. (1996). New applications for pectins. Food Technology, 3: 32-34.

Blecker, C., J.P. Chevalier, J. C. Van Herck, C. Fougnies, C. Deroane, and M. Paquot (2001). Inulin: Its physiochemical properties and technological functionality. Recent Research Development in Agricultural and Food Chemistry, 5: 125131.

Bollinger, H. (2001). Functional drinks with dietary fiber. Fruit Process, 12: 252-254.

Bonfield, C. T. (1985). Socioeconomic aspects of a fiber-deficient public diet. In G.V. Vahouny, \& D. Kritchvsky (Eds.), Dietary Fiber: Basic and Clinical Aspects New York: Plenum Press, (pp. 55-67).

Brennan, C. S. and C. M. Tudorica (2008). Carbohydrate-based fat replacers in the modification of the rheological, textural and sensory quality of yoghurt: comparative study of the utilization of barley betaglucan, guar gum and inulin. Int. J. Food Sci. Technol. 43:824-833.

Brulc, J.M., D.A. Antonopoulos, M.E. Berg Miller, M.K. Wilson, A.C. Yannarell, E.A. Dinsdale, R.E. Edwards, E.D. Frank and J.B. Emerson (2009). Gene-centric metagenomics of the fiber-adherent bovine rumen microbiome reveals forage specific glycoside hydrolases.Proc Natl Acad Sci USA., 106:1948-1953.

Burkitt, D. P. and H.C. Trowell (1975). Refined carbohydrate and disease. New York, NY: Academic Press.

Byrne, M. (1997). Low-fat with taste. Food Enginery International, 22: 36-41.

Camire, M. E., S. I. Flint (1991). Thermal processing effects on dietary fibre composition and hydration capacity in corn meal, oat meal and potato peels. Cereal Chem. 68(6):645-647.

Camire, M.E., D. Violette, M.P. Dougherty, and M.A. McLaughlin (1997). Potato peels dietary fiber composition: effects of peeling and extrusion cooking processes. J Agric Food Chem 45:1404-1409.

Caprez, A, E. Arrigoni, R. Amado and H. Neucom (1986). Influence of different types of thermal treatment on the chemical composition and physical properties of wheat bran. J Cereal Sci. 4:233-239.

Chang, M., Y. X. Zhang and Y. L. Tian (2016). Effect of supercritical CO2 on physicochemical properties of pear pomace dietary fiber, food research development. Food Research \& Development, 37 (7): 97-101,

Chau, C. F., and Y. L Huang (2003). Comparison of the chemical composition and physicochemical properties of different fibers prepared from the peel of Citrus. Journal of Agricultural and Food Chemistry, 51: 2615-2618.

Chevance, FFV, L.J. Farmer Desmond, E. Novelli, D.J. Troy and R. Chizzolini (2000) Effect of some fat replacers on the release of volatile aroma compound from low-fat meat products. J Agric Food Chem 48:3476-348

Cho, S. S., L. Prosky and M. L. Dreher (1999). Complex carbohydrates in foods: CRC Press, 676.

Chopra, H., S.A. Udipi and P. Ghugre (2009). Dietary fiber content of selected legumes: varietal differences and effect of processing. J Food Sci Technol, 46(3):266-26

Chylinska, M., M. Szyma, nska-Chargot, B. Kruk and A. Zdunek (2016). Study on dietary fiber by ourier transform-infrared spectroscopy and chemometric methods, Food Chemistry, 196: 114-122.

Codex Alimentarius Commission (2008). Codex Alimentarius Commission Report of the 30th Session of the Codex Committee on Nutrition and Foods for Special Dietary Uses; Codex Alimentarius Commission: Cape Town, South Africa.

Cofrades, S., M. A. Guerra, J. Carballo, F. Fernández-Martín and F. JiménezColmenero (2000). Plasma protein and soy fiber content effect on bologna sausage properties as influenced by fat level. Journal of Food Science, 65(2): 281-287. 
Cui, S. W., S. Nie and K. T. Roberts (2001). Functional properties of dietary fiber. Biotechnology, 4: 517-525

Davidson, M. H. and A. McDonald (1998). Fiber: Forms and function. Nutrition Research, 18: 617-624.

Dello Staffolo, M., N. Bertola, M. Martino and A. Bevilacqua (2004). Influence of dietary fiber addition on sensory and rheological properties of yogurt. International Dairy Journal, 14 (3): 263268,

Desmedt, A. and H. aJacobs (2001). Soluble fiber. In: Guide to functional food ingredients. Food RA Leatherhead Publishing, Surrey, England, pp. 112140

Dhingra, D., M. Michael, R. Rajput and R. T. Pati (2012). Dietary fiber in foods: a review. J Food Sci. Tech., 49(3):255-266

Du, C. X., M. S. Niu, and X. j. Liu (2005). The research process of modification and application of dietary fiber. Journal of Dalian Nationalities University, 5: 18-21.

Eastwood, M. A. (1987). Dietary Fiber and risk of cancer. Nutr. Rev., 7: 193

Elleuch, M., D. Bedigian, O. Roiseux, S. Besbes, C. Blecker and H. Attia (2011). Dietary fiber and fiber-rich by-products of food processing: Characterisation, technological functionality and commercial applications: A review. Food Chemistry, 124: 411-42.

Elleuch, M., S. Besbes, O. Roiseux, C. Blecker, C. Deroanne, and N.E. Drira (2008). Date flesh: Chemical composition and characteristics of the dietary fiber. Food Chemistry, 111: 676-682.

Erişim tarihi. (2013).

http://iyigelenyiyecekler.com/lifliyiyeceklernelerdir/.

Eussen, S. R. B. M., H. Verhagen, O. H. Klungel, J. -Garssen, H.van Loveren, $\mathrm{H}$. J. van Kranen and C. J. M. Rompelberg (2011). Functional foods and dietary supplements: Products at the interface between pharma and nutrition. European Journal of Pharmacology 668: 52-59.
Fadaei, V. and M. Salehifar (2013). Rice husk as a source of dietary fiber. Annals of Biological Research, 3 (3): 1437-1442.

Fagan, C.C., C. P. O'Donnell, P. J. Cullen, and C. S. -Brennan (2006). The effect of dietary fibre inclusion on milk coagulation kinetics. Journal of Food Engineering 77: 261-268.

Farvid, M.S., A.H. Eliassen , E,Cho, X. Liao, W.Y. Chen and W.C. Willett (2016). Dietary fiber intake in young adults and breast cancer risk. Pediatrics 137(3).

Feng, Z., W. Dou, S. Alaxi, Y. Niu and L. L. Yu (2017). Modified soluble dietary fiber from black bean coats with its rheological and bile acid binding properties. Food Hydrocolloids, 62: 94-101.

Fernández-López, J., M. Viuda-Martos, E. Sendra, E. SayasBarberá, C. Navarro, and J A. Pérez-Alvarez (2007). Orange fibre as potential functional ingredient for dry-cured sausages. European Food Research and Technology, 226 (12): 1-6.

Filiz Yangilar (2013). The Application of Dietary Fiber in Food Industry: Structural Features, Effects on Health and Definition, Obtaining and Analysis of Dietary Fiber: A Review. Journal of Food and Nutrition Research, 1 (3): 13-23.

Fleury N, and M. Lahaye (1991) Chemical and physicochemical characterization of fibers from Laminaria digitata (Kombu Breton): a physiological approach. J Sci. Food Agric. 55:389-400

Food and Nutrition Board, Institute of Medicine (2001) Dietary reference intakes. Proposed definition of dietary fiber. A report of the panel on the definition of dietary fiber and the standing committee on the scientific evaluation of dietary reference intakes. Washington, DC: National Academy Press.

Fuchs CS, E. L. Giovannucci, G. A. Colditz (1999). Dietary fiber and the risk of colorectal cancer and adenoma in women. N Engl. J Med. 340:169-176.

Fuller, R. and G. R. Gibson (1997). Modification of the intestinal microflora using probiotics and prebiotics. 
Scandinavian Journal of Gastroenterology Supplement, 222: 2831.

García Herrera, P., M. C. Sánchez-Mata and M. Cámara (2004). Nutritional characterization of tomato fiber as a useful ingredient for food industry. Innovative Food Science \& Emerging Technologies.11 (4): 707-11.

Garcia-Perez, F. J., Y. Lario, J. FernandezLopez, E. Sayas, J. A. Perez-Alvarez and E. Sandra (2005). Effect of orange fiber addition on yogurt color during fermentation and cold storage. Color Res Appl. 30:457-463.

Gear, J. S.S., A. Ware, P. Fursdon, J. I. Mann Nolan, A. J. M Brodribb and M.P Vessey (1979). Symptomless diverticular disease and intake of dietary fiber. Lancet 1: 511-513.

Gelroth, J. and G. S. Ranhotra (2001). Food uses of fiber. InS. Sungsoo Cho \& M.S. Dreher (Eds.), Hand book of dietary fiber. New York: Taylor and Francis, 63-268.

Gibson, G. R. and M. B. Roberfroid (1995). Dietary modulation of the human colonic microbiota: Introducing the concept of prebiotics. Journal of Nutrition, 125: 1401-1412.

Gonze, M. and F. Van der Schueren (1997). Sugar-free chocolate. Candy Industry, 162: 42-45.

Gorinstein, S., Z. Zachwieja, M. Folta, H. Barton, J. Piotrowicz, M. Zember, M. Weisz, S. Trakhtenberg and O. MartinBelloso (2001). Comparative content of dietary fiber, total phenolics, and minerals in persimmons and apples. Journal of Agricultural and Food Chemistry, 49: 952-957.

Graham, H., M. B. G. Rydberg and P. Aman (1988). Extraction of soluble dietary fiber. J Agric Food Chem 36(3): 494-497.

Grigelmo-Miguel, M., S. Gorinstein, and O. Martin-Belloso, (1999a) Characterization of peach dietary fiber concentrate as a food ingredient. Food Chemistry, 65: 175-181.
Guillon, F. and M. Champ (2000). Structural and physical properties of dietary fibers, and consequences of processing on human physiology. Food Res Int 33: 233-245.

Ham, K. K. E., H. W. Hwang and I. Kim (2016). Effects of fat replacement with a mixture of collagen and dietary fiber on small caliber fermented sausages, International Journal of Food Science and Technology, 51 (1): 96-104.

Hashim, I. B., A. H. Khalil and H. S. Aff (2009). Quality characteristics and consumer acceptance of yogurt fortified with date fiber, Journal of Dairy Science, 92 (11): 5403-5407.

Hauner, H., A. Bechthold, H. Boeing, A. Brönstrup, A. Buyken and E. LeschikBonnet (2012). Evidence-based guideline of the German nutrition society: Carbohydrate intake and prevention of nutrition-related diseases. Annals of Nutrition \& Metabolism, 60 (1): 1-58.

Hegenbart, S. (1995). Using fibers in beverages. Food Prod Des 5 (3):68-78.

Herbafood, Herbacel AQ Plus. (2002). Apple and citrus fiber. Available from www.herbafood.de/eaqplus.pdf.

Heredia, A., A. Jimenez, J. FernandezBolanos, R. Guillen, and R. Rodriguez (2002). Fibra Alimentaria. Biblioteca de Ciencias, Madrid, pp 1- 117.

Hesser JM (1994). Applications and usage of dietary fiber in the USA. Int Food Ingred. 2:50-52.

Honcu, M. Slukova, K. Vaculova, I. Sedlackova, B. wiege and E. Fehling (2016). The effects of extrusion on the content and properties of dietary fiber components in various barley cultivars. Journal of Cereal Science 68: 132-139.

Hong, Y., W. Zi-jun, X. Jian, D. Ying-jie and M. Fang (2012). Development of the dietary fiber functional food and studies on its toxicological and physiologic properties. Food and Chemical Toxicology 50: 3367-3374. 
Hoogenkamp, H. (2007). The soy industry's love-hate relationship with meat. Meat International, 17 (2): 8-11.

Huang, Y. L. and Y. S. Ma (2016). The effect of extrusion processing on the physiochemical properties of extruded orange pomace, Food Chemistry, 192: 363-369.

Institute of Medicine, National Academy of Sciences (2005). Dietary reference intakes for energy, carbohydrate, fiber, fat, fatty acids, cholesterol, protein and amino acids. Washington, DC: National Academies Press.

Jacobs, J., H. and J. A. Delcour (1998). Hydrothermal modification of granular starch, with retention of the granular structure: a review. Journal of Agriculture Food Chemistry 8: 2895-2905.

Jaime, L., E. Molla, A. Fernandez, M. Martin-Cabrejas, F. Lopez Andreu, and R. Esteban (2002). Structural carbohydrates differences and potential source of dietary fiber of onion (Allium cepa L.) tissues. Journal of Agricultural and Food Chemistry, 50: 122- 128.

Jenkins, D.J.A., T.M.S. Wolever, V Rao, R.A. Hegele, S.J. Mitchell, T.P. Ranson, P.J. Spadafora, AL. Jenkins and C. Mehling (1993). Effect on blood lipids of very high intakes of fiber in diets low in saturated fat and cholesterol. N Eng. J. Med. 329: 21-26.

Jimenez, A., R. Rodriguez, I. FernandezCaro and R. Guillen (2000). FernandezBolanos, J. and Heredia, A., Dietary fiber content of table olives processed under different European styles: Study of physicochemical characteristics. Journal of the Science of Food and Agriculture, 80: 1903-1908.

Jiménez-Colmenero, F., M. J. Ayo and J. Carballo (2005). Physicochemical properties of low sodium frankfurter with added walnut: Effect of transglutaminase combined with caseinate, $\mathrm{KCl}$ and dietary fiber as salt replacers. Meat Science, 6 (4): 781-788.

Julie Miller Jones (2014). CODEX-aligned dietary fiber definitions help to bridge the 'fiber gap', Jones Nutrition Journal 13:34. http://www. nutritionj.com/content/13/1/34.

Kay RM, and A. S. Truswell (1977). Effect of citrus pectin on blood lipids and fecal steroid excretion in man. Am J Clin. Nutr. 30:171-175.

Kendall, C. W. C., A. Esfahani and D. J. A. Jenkins (2010). The link between dietary fiber and human health. Food Hydrocolloids 24: 42-48.

Knuckles, B. E., C. A. Hudson, M. M. Chiu and R. N. Sayre (1997). Effect of betaglucan barley fractions in high-fiber bread and pasta.. Cereal Foods World, 42: 9496.

Kunzek, H.S., S. Müller, S. Vetter and R. Godeck (2002). The significance of physico chemical properties of plant cell wall materials for the development of innovative food products. European Food Research and Technology, 214 (5): 36137.

Lambo, A. M., R. Oste and M. E. Nyman (2005). Dietary fibre in fermented oat and barley $\beta$ - glucan rich concentrates. Food Chem. 89: 283-293.

Larrauri, J. A. (1999). New approaches in the preparation of high dietary fiber powders from fruit by-products. Trends in Food Science and Technology, 10: 3-8.

Larrauri, J. A., B. Borroto, U. Perdomo and Y. Tabares (1995). Manufacture of a powdered drink containing dietary fiber: FIBRALAX. Alimentaria 260:23-25.

Larrauri, J.A., B. Borroto and A.R. Crespo (1997). Water recycling in processing orange peel to a high dietary fiber powder. Int. J. Food Sci. Tech., 32: 7376

Larrea, M.A., Y.K. Chang, and F.M. Bustos (2005). Effect of some operational extrusion parameters on the constituents 
of orange pulp. Food Chemistry 89: 301308.

Li, S. F., L. P. Hao, X. P. Yin and Y. L. Su (2003). Study on the Optimum of Almond Oil Extraction by Enzyme. Cereals and Oils Processing, 6: 40-41.

Liu, C. M., W. Liu, and J. Wan (2005). Influence of instantaneous high pressure treatment on the solubility of dietary fiber. Food Science 8: 110-113.

Liu, C., M. W. Liu and J. Wan (2005). Influence of instantaneous high pressure treatment on the solubility of dietary fiber, Food Science, 15 (4): 247-262.

Liu, Y. (2008). Study on the extraction technics conditions and characteristics of dietary fiber from citrus peel by fermentation with lactobacillus and Trichoderma viride. Sichuan Agricultural University, a Master's degree Thesis.

Ma, Y. X., Y. Wang and Y. Gao (2005). Study on multifunctional activation of soy bean dietary fiber. Science and Technology of Cereals, Oils and Foods 5: 35-36.

Makała, H. and M. Olkiewicz (2004). Role of selected wheat and oat cellulose preparations in binding water in finely comminuted model meat products. Acta Agrophysica, 4 (1): 85-96.

Mańas, E. (1992). AnaÂ lisis de fibra alimentaria. Fuentes de error en los meÂtodos actualesy propuesta de nueva metodologõ̂̂a. Sc. D. Thesis. University of AlcalaÂ de Henares, Madrid, Spain.

Mansour, E. H. and A. H. Khalil (1999). Characteristics of low-fat beef burgers as influenced by various types of wheat fibers. J. Sci. Food Agric. 79:493-498.

Martin, K. (1999). Replacing fat, retaining taste. Food Enginery International, 24: 57-59.

Martinez-Saez, N., A. T. Garc'ia and I. D. Perez (2017). Use of spent coffee grounds as food ingredient in bakery products, Food Chemistry, 216: 114-122.
McKeown, N. M., J. B. Meigs, S. Liu, E. Saltzman, P. W. Wilson and P. Jacques (2004). Carbohydrate nutrition, insulin resistance, and the prevalence of the metabolic syndrome in the Framingham Off spring . Cohort. Diabetes Care. 27:538-46.

McKeown, NM, J. B. Meigs, S. Liu, P. W. Wilson and P. F. Jacques (2002). Wholegrain intake is favorably associated with metabolic risk factors for type 2 diabetes and cardiovascular disease in the Framingham Offspring Study. Am J Clin. Nutr., 76:390-8.

Mitchell, H. L. (2003). Fiber-enriched beverages and Litesse Registered. Soft Drinks International, pp. 25-27.

Mitsuro Chiba, Tsuyotoshi Tsuji, Kunio Nakane and Masafumi Komatsu (2015). High Amount of Dietary Fiber Not Harmful But Favorable for Crohn Disease. Perm. J. 19(1): 58-61 Original research \& contributions http://dx.doi.org/10.7812/TPP/14-124.

Mongeau, R. and S.P.J. Brooks (2016). Dietary fiber: Determination. Encyclopedia of Food and Health pp. 383-39.

Nassar, A.G., A.A. AbdEI-Hamied and E. A. El-Naggar (2008). Effect of citrus byproducts flour incorporation on chemical, rheological and organoleptic characteristics of biscuits. World J. Agric. Sci. 4 (5): 612-616.

Nelson, A. L. (2001). High-fiber ingredients: Eagan press handbook series. St Paul, MN: Eagan Press.

Ng, S. P., C. P. Tan, O. M. Lai, K. Long and H. Mirhosseini (2010). Extraction and characterization of dietary fiber from coconut residue. Journal of Food Agriculture \& Environment, 8 (2): 172177.

Ng, A., S. Lecain, M. L. Parker, A. C. Smith and K. W. Waldron (1999). Modification of cell wall polymers of onion waste. III. Effect of extrusion-cooking on cell wall 
material of outer fleshy tissues. Carbohydrate Polymers 39: 341-349.

O'Shea, N., E. K. Arendt and E. Gallagher (2012). Dietary fiber and phytochemical characteristics of fruit and vegetable byproducts and their recent applications as novel ingredients in food products. Innovative Food Science and Emerging Technologies 16:1-10.

Park, K. H, K. Y. Lee and H. G. Lee (2016). Chemical composition and physicochemical properties of barley dietary fiber by chemical modification, International Journal of Biological Macromolecules, 60 (6): 360-365.

Pereira MA, E. O'Reilly and K. Augustsson (2004). Dietary fiber and risk of coronary heart disease: a pooled analysis of cohort studies. Arch Intern Med. 164:370376.

Periago, M.J.G., G. Ros, G. Lo 'pez, M.C. Martinez and F. Rincón (1993). The dietary fiber components and their physiological effects. Revista Espan olade Cienciay Tecnologia de Alimentos, 33: 229-246

Pietrasik, Z. and Z. Duda (2000). Effect of fat content and soy protein/carrageenan mix on the quality characteristics of comminuted scalded sausages. Meat Science, 56: 181-188.

Pins, J. J., D. Geleva, K. Leemam, C. Frazer, P. J. O'Connor and L. M. Cherney (2002). Do whole-grain oat cereals reduce the need for antihypertensive medications and improve blood pressure control. Journal of Family Practice, 51: 353-359.

Pomeranz, Y., M. D. Shogren, K. F. Finney, and D. B. Bechtel (1977). Fiber in bread effects on functional properties. Cereal Chemistry, 54: 25-41.

Prosky L, N. G. Asp, I. Furda, J. W. DeVries, T. F. Schweizer, and B. F. Harland (1984). Determination of total dietary fiber in foods and food products:
Col laborative study. JAOAC 67: 10441052.

Qi, B., L. Jianga, Y. Lia, S. Chena, X. Suia, (2011). Extract dietary fiber from the soy pods by chemistry enzymatic methods. Procedia Engineering 15: 4862-4873.

Raghavendra, S. N., S. R. Ramachandra Swamy, N. K. Rastogi, K.S.M.S. Raghavarao, S. Kumar and R. N. Tharanathan (2006). Grinding characteristics and hydration properties of coconut residue: a source of dietary fiber. J Food Eng. 72:281-28

Ramirez-Santiago, C., L. Ramos, -Solis, C. Lobato-Calleros, C. -PeñaValdivia, E. J. Vernon-Carter and J. Alvarez-Ramírez (2010). Enrichment of stirred yogurt with soluble dietary fiber from Pachyrhizus erosus L. Urban: Effect on syneresis, microstructure and rheological properties. Journal of Food Engineering, 101: 229235.

Redondo, A., M. J. Villanueva and M. D. Rodr'ıguez (1994). Highperformance liquid chromatographic determination of dietary fiber in raw and processed carrots. Journal of Chromatography, 677 (2): 273-278.

Renard, C.M.G.C., M. J. Crepeau and J. F. Thibault (1994). Influence of ionic strength, $\mathrm{pH}$ and dielectric constant on hydration properties of native and modified fiber from sugar-beet and wheat bran. Ind Crops Prod 3:75-84

Roberfroid, M., G. R. Gibson, L. Hoyles, A. L. McCartney, R. Rastall, I. Rowland, D. Wolvers, B. Watzi, H. Szajewska and B. Stahl (2010). Prebiotic effects: metabolic and health benefits. Br J. Nutr. 104 (2): 51-63.

Rodríguez, R. A. J., J. Fernández-Bolaños, R. Guillén and A. Heredia (2006). Dietary Fiber from Vegetable Products as a Source of Functional Ingredients. Trends in Food Sciences and Technology, 17: 315. 


\section{Health benefits, extraction and utilization of dietary fibers: A review}

Rodriguez, R., A. Jimenez, J. FernandezBolanos, R. Guillen and A. Heredia (2006). Dietary fiber from vegetable products as source of functional ingredients. Trends in Food Science and Technology, 17.

Rolls, B. J., E. A. Bell, V. H. Castellanos, M. Chow, C. L. Pelkman, L. U. Thompson and R. G. Josse (1999). Energy density but not fat content of foods affected energy intake in lean and obese women. Am J Clin. Nutr. 69(5):863-871.

Salmeron, J., J. E. Manson, M. J. Stampfer, G. A. Colditz, A. L. Wing and W. C. Willet (1997). Dietary fiber, glycemic load and risk of non-insulin dependent diabetes mellitus in women. JAMA 277: 472-477.

Salyers, A. A., S. E. H. West, J. R. Vercelotti and T. D. Wilkins (1977). Fermentation of mucins and plant polysaccharides by anaerobic bacteria from the human colon. Appl. Environ. Microbiol. 34:529533.

Sánchez-Zapata, E., J. Fernández-López, E. Sendra, M. E. SayasBarbera, C. Navarro and M. Viuda-Martos (2008). Effect of orange fiber on the colour and hemeiron content of "paté" elaborated with dark muscle ("Sangacho") of bluefin tuna (Thunnus thynnus). In: Proceedings of international functional foods conference. EULAFF/CYTED (p. 80). Porto, Portugal.

Sangnark, A. and A. Noomhorm (2004). Chemical, physical and baking properties of dietary fiber prepared from rice straw. Food Research International, 37: 66-74.

Sanz, T., A. Salvador, A. Jimenez and S. Fiszman (2008). Yogurt enhancement with functional asparagus fiber, effect of fiber extraction method on rheological properties, colour and sensory acceptance. Eur Food Res Technol 227:1515-1521

Scharlau, D., A. Borowicki, N. Habermann, T. Hofmann, S. Klenow, C. Miene, U. Munjala, K. Stein and M. Gleia (2009). Mechanisms of primary cancer prevention by butyrate and other products formed during gut floramediated fermentation of dietary fiber. Mutation Research/Reviews in Mutation Research, 682: 39-53.

Schweizer, TF and P. Wursch (1979). Analysis of dietary fiber. J Sci. Food Agric. 30:613-619.

Sendra, E., P. Fayos, Y. Lario, J. Fernández-López, E. SayasBarberá and J. A. Pérez-Alvarez (2008). Incorporation of citrus fibers in fermented milk containing probiotic bacteria. Food Microbiology, 25 (1): 13-22.

Sharif, M. K., S. B. Masood, M. A. Faqir and H. Nawaz (2009). Preparation of fiber and mineral enriched defatted rice bran supplemented cookies. Pakistan J Nutr 8(5): 571-577.

Singanusong, R., W. Tochampa, T. Kongbangkerd and C. Sodchit (2013). Extraction and properties of cellulose from banana peels. J. Sci. Technol. 21(3): 201-213.

Siró, I., E. Kápolna and A. Lugasi (2008). Functional food. Product development, marketing and consumer acceptance -a review. Appetite. 51 (3): 456-67.

Slavin, J. L., D. Jacobs, L. Marquart and K. Wiemer (2001). The role of whole grains in disease prevention. Journal of the American Dietetic Association, 101: 780785.

Soukoulis, C., D. Lebesi and C. Tzia (2009). Enrichment of ice cream with dietary fiber: Effects on rheological properties, ice crystallization and glass transition phenomena. Food Chemistry, 115: 665671.

Steinmetz, K. A. and J. D. Potter (1991). Vegetables, fruit, and cancer. I. Epidemiology. Cancer Causes and Control, 2: 325-357.

Sudha, ML, V. Baskaran and K. Leelavathi (2007). Apple pomace as a source of dietary fiber and polyphenols and its effect on the rheological characteristics 
and cake making. Food Chem 104: 686692.

Takahashi, H., N. Wajo, T. Okubo, N. Ishihara, J. Yamanaka and T. Yamamoto (1994). Influence of partially hydrolyzed guar gum on constipation in women. J Nutr Sci Vitaminol 40: 151-159

Takahashi, H., S. I. Yang, C. Hayashi, M. Kim, J. Yamanaka and T. Yamamoto (1993). Effect of partially hydrolyzed guar gum on fecal output in human volunteers. Nutr Res 13: 649-657.

Talukder, S. (2015). Effect of dietary fiber on properties and acceptance of meat products: a review," Critical Reviews in Food Science and Nutrition, 55 (7): 1005-1011.

Telrandhe, U. B., R. Kurmi, V. Uplanchiwar, M. H. Mansoori, V. J. Raj and K. Jain (2012). Nutraceuticals- A phenomenal resource in modern medicine. International Journal of Universal Pharmacy and Life Sciences, 2(1): 179195.

Thebaudin, J. and A. C. Lefebvre (1997). Dietary fiber: Natural and technological interest. Trends in Food Science and Technology, 8: 41-48.

Thed ST, and R. D. Philips (1995). Changes of dietary fiber and starch composition of processed potato products during domestic cooking. Food Chem 52:301304.

Thibault, JF, M. Lahaye and F. Guillon (1992). Physiochemical properties of food plant cell walls. In: Schweitzer T F, Edwards C A (Eds.) Dietary fiber, a component of food. Nutritional function in health and disease. Springer-verlag, Berlin, pp. 21-56Toma RB, Orr PH, Appolonia BD, Dintzis FR, Tabekhia MM (1979) Physical and chemical properties of potato peel as a source of dietary fiber in bread. J Food Sci. 44:1403-1407.

Toma, R. B., P. H. Orr, B. D. Appolonia, F. R. Dintzis and M. M. Tabekhia (1979). Physical and chemical properties of potato peel as a source of dietary fiber in bread. J Food Sci. 44:1403-1407.

Trowell, H., D. Burkitt and K. Heaton (1985). Dietary Fiber, Fiber-Depleted Foods and Disease, London: Academic Press, pp. 133-315.

Trowell, H. (1972). Fschaemic heart disease and dietary fiber. American Journal of Clinical Nutrition, 25, pp 926-932.

Trumbo, P., S. Schlicker, A. Yates and M. Poos (2002). Dietary reference: intakes for energy, carbohydrate, fiber, fat, fatty acids, cholesterol, protein, and amino acids. Journal of the American Dietetic Association, 102 (11): 1621-1630.

U.S. Food and Drug Administration (2011). Dietary Supplements Health and Education Act of 1994 (Available from :) http://www.fda.gov/Regulatorylnformation Legislation/Federal Food Drug and Cosmetic Act FDC Act/Significant Amendments to the FDC Act/ucm148003.htm.

Van Kreijl, C. F., A. G. A. C. Knaap and J. M. A. van Raaij (2006). Our food, our health: healthy diet and safe food in the Netherlands, pp. 189-213.

Varo, P., R. Laine and P. Koivistoinen (1983). Effect of heat treatment on dietary fiber: inter laboratory study. J Assoc. Of Anal. Chem. 66 (4):933-938.

Verma, A. K. and R. Banerjee (2010). Dietary fiber as functional ingredient in meat products: a novel approach for healthy living-a review. J Food Sci. Technol. 47(3):247-257.

Vidal-Valverde C, J. Frias and R. Esteban (1992). Dietary fiber in processed lentils. J Food Sci. 57:1161-63.

Viuda-Martos, M., Y. Ruiz-Navajas, J. Fernández-López, J. A. Pérez- Álvarez (2010). Effect of orange dietary fiber, oregano essential oil and packaging conditions on shelf-life of bologna sausages. Food Control, 21 (4): 436-443.

Wang, J. H., L. K. Cao and Y. X. Ma (2004). Study on producing high active dietary 
from soy bean residue. Jilin Agricultural Sciences 3: 53-57.

Wang, J., C. M. Rosell and C. B. Barber (2002). Effect of the addition of different fibers on wheat dough performance and bread quality. Food Chemistry, 79: 221226.

Waszkowiak, K. and K. Szymandera-Buszka (2008). The application of wheat fiber and soy isolate impregnated with iodine salts to fortify processed meats. Meat Science 80: 1340-1344.

Wen Han, Sen Ma, Li Li, Xiao-xi Wang and Xue-ling Zheng (2017). Application and Development Prospects of Dietary Fibers in Flour Products. Journal of Chemistry Volume 2017 Article ID 2163218, 8 pages.

https://doi.org/10.1155/2017/2163218

WHO/FAO (2003). Food energy - methods of analysis and conversion factors. Report of a technical work shop, FAO Food and Nutrition Paper - 77, Rome.
Wilson, A. J., A. C. Chueh, L. Togel, G. A. Corner, N. Ahmed, S. Goel, D. S. Byun, S. Nasser, and M. A. Houston (2010). Apoptotic sensitivity of colon cancer cells to histone deacetylase inhibitors is mediated by a Sp1/Sp3-activated transcriptional program involving immediate-early gene induction. Cancer Res.70:609-620.

Yamazaki, E., K. Murakami and O. Kurita (2005). Easy Preparation of Dietary Fiber with the High Water-Holding Capacity from Food Sources. Plant Foods for Human Nutrition 60: 17-23.

Yue-yue Yang, Sen Ma, Xiao-xi Wang and Xue-ling Zheng (2017). Modification and Application of Dietary Fiber in Foods Journal of Chemistry https://doi.org/10.1155/2017/9340427

Zhang, H., Z. G. Xiao and D. Wang (2011). Advances and prospect on extraction process of soluble dietary fiber in soybean dregs. Soybean Science and Technology 5: 27-30. 


\section{الفوائد الصحية وإستخلاص وإستخام الألياف الغذائية: بحث مرجعي}

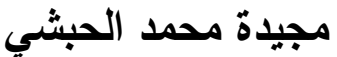

قسم علوم وتكنولوجيا الأغذية - كلية الزراعة - جامعة المنوفية - مصر اليبر

الملخص العربى

الألياف الغذائية هي عبارة عن الجزء النباتي في الوجبة الغذائية والتي لا تهضم بواسطة أنزيمات القناة الهضمية. وتثتمل الألياف الغذائية علي كل من السليلوز والمواد البكتينية والصموغ والميسيلاج والمادية الكيادة الغير كربوهيدراتية (اللجنين).

تقسم الألياف الغذائية إلي نوعين تبعا للذوبان في الماء وهما الألياف الغذائية الذائبة والغير ذائبة وكلاهما له تأثير فسيولوجي مختلف.

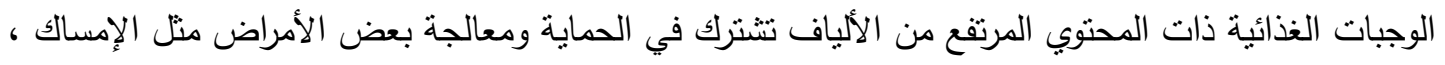
أمراض إلتهاب الأمعاء ، السرطان ، أمراض القلب ومرض السات السكر ـ الإحتياج اليومي من الألياف للبالغين هو الإن 38

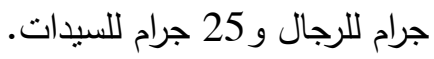

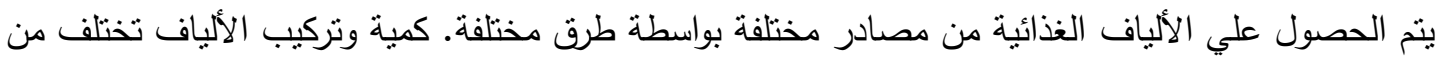

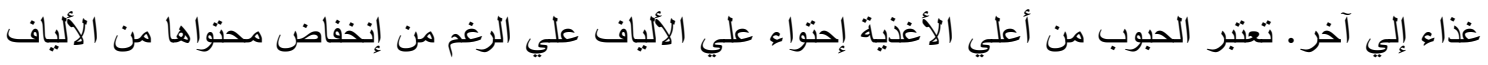

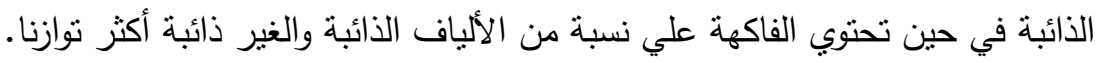
كثير من المعاملات وطرق التصنيع منل الطبخ مع البثق الحراري - التعليب - الطحن - الغلي - التجميد

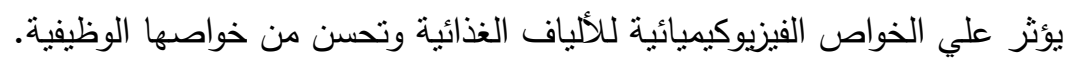

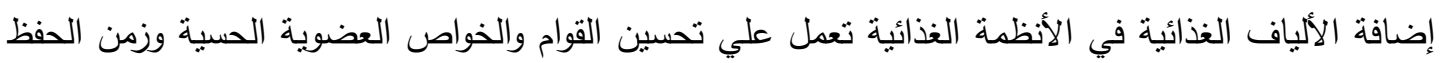

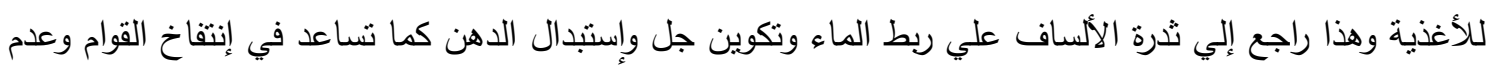
الإلتصاق.

يمكن إستخدام الألياف الغذائية في العديد من الأغذية الوظيفية متل منتجات الهخابز ، الششروبات ومنتجات

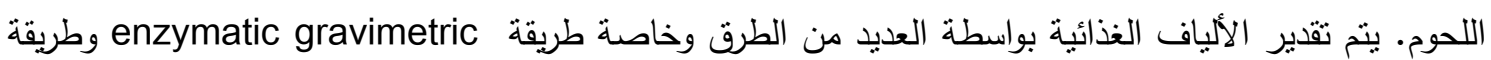
. enzymatic chemical methods الكلمات الإرشادية : الألياف الغذائية - تقسيمها - مصادرها - الفوائد الصحية - طرق التقدير والإنتخلاص تطبيقات في الصناعة. 